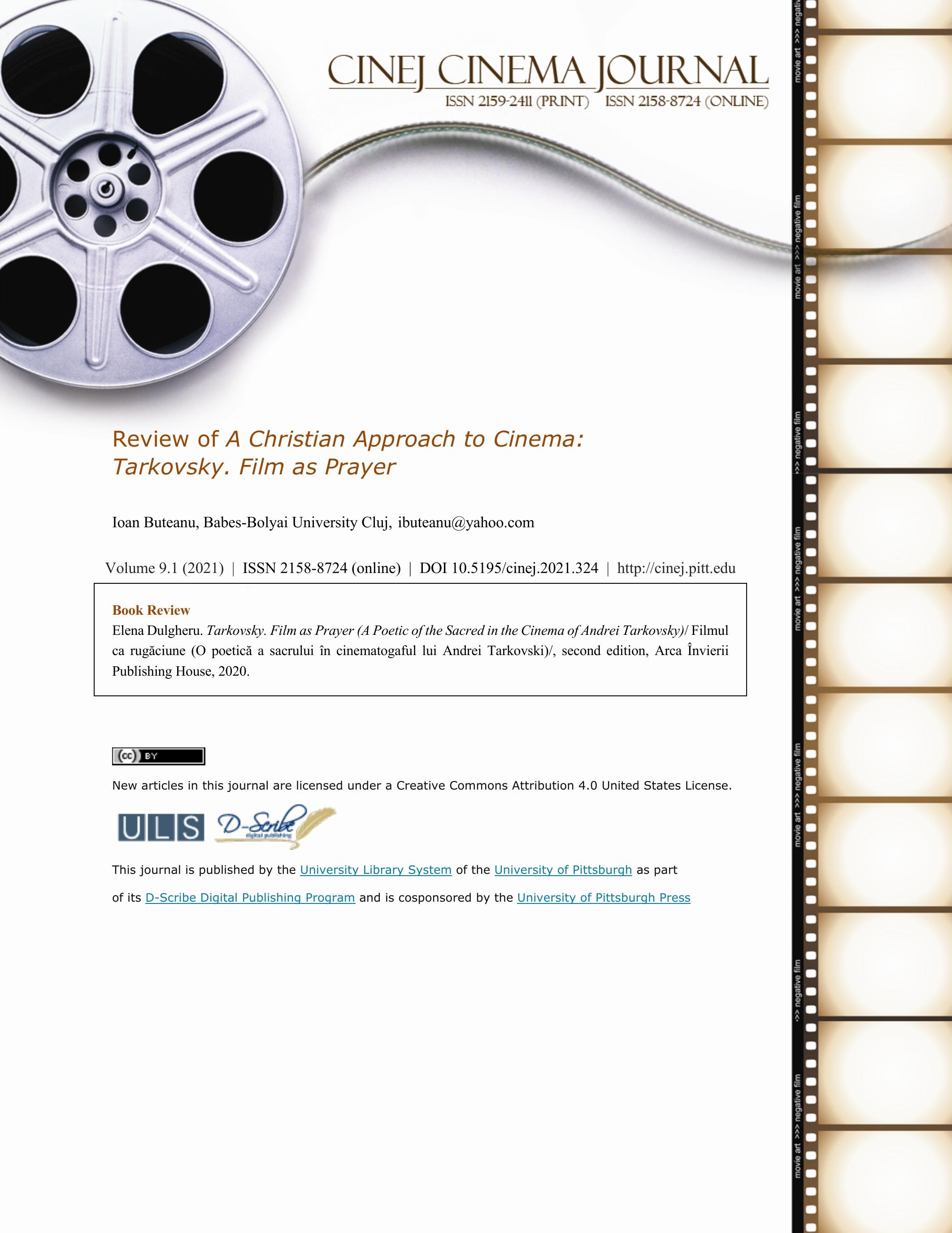





\section{Review of A Christian Approach to Cinema: Tarkovsky. Film as Prayer Ioan Buteanu}

In the preface to this book, by its original title Tarkovski. Filmul ca rugăciune (O poetică a sacrului în cinematogaful lui Andrei Tarkovski), Manuela Cernat said: "Compared to the numerous exegetes of this director, Elena Dulgheru is the first, and, for the time being, the only who has the intuition to decipher his creation in the Christian Orthodox key" (qtd in Dulgheru 9).

The book starts with a detailed "sketch of the artistic biography" (Dulgheru 11) of the director preceded by an "argument". From this "argument", often expressed in long and complicated phrases, we find out that the author sees the role of this first chapter important in order to "organize, chronologically, as far as possible, and present in the most appropriate context the biographical material" (Dulgheru 14). Here the parents of Andrei are presented (the mother, Maria Ivanovna, more detailed, and the father, Arseni, somehow more succinct). The childhood atmosphere is well depicted. Parents' separation and the effects of war take an important role in shaping this atmosphere. The period of studies, first short films, the marriage with and the divorce from Irma Raush, the birth of Arseni, the first son, are also presented. The chapter then presents, in chronological order, the films of the director framed in the personal, social and political context in which they appeared, followed by their national and international reception. In this manner are introduced in the book Ivan's Childhood, Andrei Rublev (which was not allowed by the Soviets to enroll in the official competition at Cannes in 1969), Solaris, The Mirror, Stalker, Nostalghia and The Sacrifice.

Here are also mentioned his second marriage, that with Larisa Egorkina, the birth of Andrei, the second son (in 1970) (Dulgheru 44), the heart attack suffered by the director in 1978, 
the death of his mother in 1979. The constant bad treatment he receives from the Soviet authorities determines him, in 1984, to remain in Italy with his wife. Then he will move to Germany and France (Dulgheru 64). In Sweden he will be filming The Sacrifice in 1985. His son is allowed to follow his parents only in January 1986 (Dulgheru 64-65). Andrei Tarkovsky dies at the end of the same year in France, where he is buried in the Sainte-Genevieve-des-Bois cemetery (Dulgheru $66)$.

In the "argument" justifying the existence of this book, the author claims that "a philosophical and religious approach" seemed "more fecund and more in the spirit of the work than a strictly cinematic one" (Dulgheru 73). We are cautioned that the purpose of the present work is to study "the diagonal of the spirit" and "the resonance nodes that make so ample the artistic message of his work" (Dulgheru 73). The book is further organized in five parts. The first debates the possibility of representing the sacred in art, the second discusses space, and especially the sacred space in Tarkovsky's films. "Transcendental in cinema" is defined here

not as much as what is filmed, but mostly through how it is filmed, the mystic artist is different from the, let's say, laic one (...) by way of looking at things, his gaze is always correlated with something else, so that the thing in the frame (respectively, from the frame of the painting) is only one of the ellipse poles, the other pole is outside, and the artwork (...) only draws, insinuates the way to the other pole (Dulgheru 85).

The most interesting moments of analysis are those related to the archetype of 'house' and the structure of Tarkovsky's films from this perspective. The following categories are obtained: "The Parental Home: Solaris", "The Childhood House: The Mirror", "House as Object of Offering: The Sacrifice", "The Borrowed House: Nostalghia", "The Lack of the House: Ivan's Childhood", "Man has no home on Earth: Ivan's Childhood" and "The Tabor House: Stalker". The third part, that deals with the question of time, borrows Lucian Blaga's model of 'temporal horizons': "time- 
basin (future-oriented), cascade time (emphasizing the idea of the past) and river-time" (the one of the permanent present, of the moment) (Dulgheru 116). The Christian perspective of interpretation becomes particularly evident when the author is highlighting an "inverse time of repentance" in Stalker:

How else can be explained the soul rejuvenation that the adventurers of destiny hope (and which Stalker seems to have experienced) than by going into a tunnel in which time runs in the opposite direction? (...) The return from sin through repentance and sufferings is not precisely the moral action of turning backwards, in the opposite direction? (Dulgheru 120-121)

The fourth section of the book, entitled "The Christ Motif", contains subchapters with a very diverse content of ideas, perhaps too diverse to fit under this title. We note here the interference between cinema and icon art, the interpretation of the presence and significance of animals and the "poetics of the four elements" (earth, water, air and fire) in Andrei Tarkovsky's films. In a special way, my attention was drawn by the fifth part, which is the epilogue of the book and is subtitled "Pray for Artists!", because it contains important moments of general reflection about a possible relation between theology and the artistic act. This book is meant to be a plea for the dialogue between art and theology, because "if theology asserts (...) that for the understanding and explanation of God's attributes and work, it does not need art, art cannot dispense with religion" (Dulgheru 192). Art is understood as one of the "languages of the world", a language that can speak, in the author's view, about "the religious life spent outside the temple of God, in secular activities", and theology would be much poorer, quite inconceivable, if it 'refuses' "to know the languages of the world" (Dulgheru 192). The author, therefore, considers that the Church should be more open and more eager to unveil the 'divine spark' in people in their worldly manifestations: "Maybe here - in the disregard of the world, in ignoring the divine spark of the fellow human beings and the secular activities - has its origins the progressive separation between Church and 
society?" (Dulgheru 193). One of the benefits of the dialogue between film and theology may be the development of the critic-theologian's attention to the same truths, illuminated on one side by the divine revelation and on the other by the artistic inspiration.

Another form of intersection between theology and art is that of art understood as prayer. And ideal exemplifications for this situation are the films and testimonies of Andrei Tarkovsky. The whole book of Elena Dulgheru is based on Andrei Tarkovsky's words chosen as motto: “Art is a form of prayer. Man only lives through prayer "(qtd Dulgheru 3). These words are completed and nuanced by another definition of art given by the film director: "Creation is one of the worthy moments in which we resembled the Creator, that is why I never believed in an art independent from the Supreme Builder, an art without God. The meaning of art is prayer, it is my prayer. If this prayer, if my films can bring people to God, the better. Then my life will gain its full meaning: that of serving" (qtd Dulgheru 190). Both quotes show a coherent vision of art, that of both the individual prayer and the help for others, as a way to open their souls to God.

Elena Dulgheru's book is a monographic one, referring to the life and work of a single film director who had clearly affirmed his vision about art as prayer. Her work uses the concept of the "sacred." Elena Dulgheru makes a brief reference to Mircea Eliade and prefers to cite a definition of symbol (as a common element of expression of art and religion) which, from the perspective of Pavel Florenski, is "an organic unit of the representer and of the represented" (Florenski qtd Dulgheru 75). Written from the perspective of the dialogue between religion and cinema, this book offers a revealing understanding of the motivations behind Tarkovsky's work.

\section{REFERENCES:}

E. Dulgheru. (2020). Tarkovsky. Film as Prayer (A Poetic of the Sacred in the Cinema of Andrei Tarkovsky)/Romanian: Filmul ca rugăciune (O poetică a sacrului în cinematogaful lui Andrei Tarkovski)/, second edition, Arca Învierii Publishing House. 